\title{
Az új médiaszolgáltatások terjedése
}

A cikk rámutat, hogy az elmúlt években a fejlett országok médiafogyasztási szerkezete jelentősen átalakult. Egyre nagyobb szerepet kap az interaktív médiahasználat, elsősorban a szélessávú internet-kapcsolatok révén, de az elkövetkező években a digitális televíziózás és a mobil televíziózás terjedésére is számítani lehet. A fogyasztói szokások átalakulásában a müszaki innovációk mellett a változó szabályozási, illetve üzleti környezet is szerepet játszik. A korábbi passzív fogyasztói attitűd mellett kialakulóban van a személyre szabott, aktív médiahasználat. A szerző Rogers diffúziós elmélete alapján elemzi az új szolgáltatások terjedését. Az általa végzett empirikus kutatás igazolta, hogy Magyarországon a szélessávú technológia innovátorai jól megkülönböztethetők a nagyközönség egészétől, ugyanakkor ez a gyakran homogénnek tekintett csoport valójában közel sem egységes, hanem a demográfiai és a használati jellemzők alapján egymástól jól elkülöníthető típusokból tevődik össze.

Kulcsszavak: média-fogyasztás, interaktivitás, diffúziós elmélet, szélessávú internet

\section{Szerzői információ:}

\section{Urbán Ágnes}

Közgazdász a Budapesti Corvinus Egyetem Marketing és Média Intézetének adjunktusa. PhDfokozatát 2006-ban szerezte, disszertációjának címe „Az új médiaszolgáltatások piaci fogadtatása”. Kutatási területe az új média (digitális televízió, internet, mobil média), különös tekintettel a fogyasztói szokások és az üzleti modellek átalakulására. Több tudományos közlemény és könyvfejezet szerzóje. A Médiakutató címú folyóirat szerkesztóbizottságának tagja, a COST 298 (Participation in Broadband Society) páneurópai kutatási program résztvevóje.

E-mail. agnes.urban@uni-corvinus.hu

Így hivatkozzon erre a cikkre:

Urbán Ágnes. „Az új médiaszolgáltatások terjedése”. 
Urbán Ágnes

\section{Az új médiaszolgáltatások terjedése}

\section{Bevezetés}

A médiagazdaságtani kutatások fókusza az elmúlt években egyértelmúen megváltozott. Míg korábban a hagyományos média (lapkiadás, rádiós és televíziós músorszolgáltatás) piacának vizsgálata, az üzleti modellek változása kapott kiemelt figyelmet, addig mára az ún. új média került az érdeklődés középpontjába. A technológiai fejlódésnek köszönhetốen új médiumok születtek, de távolról sem csupán múszaki újdonságokról van szó. Az új eszközök egyben új szolgáltatások megjelenéséhez vezettek, s ez a korábbiaktól radikálisan eltérő fogyasztói szokások kialakulását vonja maga után. Az új médiának nincs a szakirodalomban széles körben elfogadott definíciója, de értelmezésem szerint ide sorolható minden olyan tömegkommunikációs eszköz és szolgáltatás, amely lehetôvé teszi az interaktív hozzáférést és a médiatartalmak személyre szabását.

Ma még nehéz megmondani, hogy az interaktív szolgáltatások terjedésében hosszú távon a számítógépes hálózat (internet), a digitális televíziózás vagy pedig a mobiltechnológia fog-e domináns szerephez jutni, annyi azonban kétségtelen, hogy az elmúlt években a médiafogyasztási szokások radikális átalakulásának lehettünk tanúi. A kétirányú kapcsolatot biztosító technológiák felhasználásával ma már mindenki maga állíthatja össze az igényeinek megfelelố médiatartalmat, legyen szó hírekról, filmekról vagy bármilyen más szórakoztató múfajról.

E tanulmány az új média piacának legfóbb jellegzetességeit foglalja össze, majd Rogers (2003) diffúziós elméletére támaszkodva felvázolja az innovációk piaci terjedésének ütemét, a fogyasztói elfogadás különbözó fázisait. Külön vizsgálatot igényel, hogy az új médiára milyen korlátokkal és milyen eltérésekkel alkalmazható a diffúziós elmélet. Az új típusú szolgáltatások felhasználóira jellemzó demográfiai adatok és médiafogyasztási szokások feltárása és elemzése céljából empirikus kutatást végeztem a magyarországi széles sávú internet-elófizetók körében.

\section{Az új média és az interaktivitás}

Az interaktivitás megjelenése először leginkább az internethez kötődött, de a digitális televíziózás különbözố platformjai (földfelszíni, kábeles, múholdas músorterjesztés), valamint a mobilszolgáltatók is hasonló jellegú tartalom- és kommunikációs szolgáltatásokat képesek nyújtani. Az interaktivitás mint médiahasználati jellemzố vonás tehát kevéssé függ az alkalmazott technológiától.

Magyarországon az interaktív médiaszolgáltatások ugyan még csak aránylag szúk körben érhetók el, de az internethasználat aránya emelkedik: az Eurostat adatai szerint 2006-ban már a háztartások 22\%-a volt ellátva széles sávú internettel. Az internet önma- 
gában is biztosítja az interaktivitást a felhasználók számára, de egyik potenciálisan népszerú szolgáltatása, az IPTV még csak korlátozottan érhetố el (jelenleg a T-online és a TVnet kínálja ügyfeleinek). A digitális televíziózás még gyermekcipóben jár, bár a múholdas platformon két szolgáltatás (UPG Direct és DigiTV) már elérhetô, és egy cég (a T-kábel) a kábelpiacon is kínál ügyfeleinek digitális szolgáltatást. A földfelszíni digitális televíziózás üzemszerú elindítása komoly szabályozási elókészítést igényel, amire van ugyan kormányzati szándék, de ennek kimenetele több mint bizonytalan. Ami a mobil tartalom piacát illeti, itt is a video, illetve televíziós szolgáltatások terjedése a legizgalmasabb kérdés. Jelenleg a 3G (harmadik generációs) rendszereken már elérhetók televíziós tartalmak, de a mobil músorszórás beindulása - hasonlóan a digitális földfelszíni músorszóráshoz - még évekbe telhet.

Megállapítható tehát, hogy Magyarországon az új média piaca fejletlen, a szolgáltatások még csak korlátozottan érhetók el. Egyelớre az internet esetében jelenthetô ki leginkább, hogy a használat gátja elsôsorban nem a kínálati, hanem a keresleti oldalon van. Az internethasználat még nagyobb mértékü elterjedésének természetesen lehetnek hozzáférési vagy jövedelmi akadályai is, de kétségtelen, hogy a felhasználáshoz szükséges képességek megszerzése, a fogyasztói szokások megváltozása is idôigényes folyamat. Az interaktív médiafogyasztás iránti fogyasztói igény kialakulása nem történik meg egyik napról a másikra, és amíg a tömeges igény nem alakul ki, addig a szolgáltatás terjedése sem gyorsul fel igazán.

Az interaktivitás kérdése különösen élesen vetôdik fel a videotartalmak fogyasztása esetében. A hagyományos televíziózás a passzivitásra épül: a fogyasztás jól ismert módja az, amikor a nézó ül a készülék elótt egy pohár sörrel a kezében, valamit rágcsálva - ennek a felhasználótípusnak a jellemzésére született meg a magyarra nehezen lefordítható couch potato kifejezés. Kétségtelen, hogy ez a magatartástípus létezik: a nézók nagy része az egész napi fárasztó munka után jellemzóen csak pihenni akar, a személyre szabott tartalom összeállítása, gyakorlatilag a saját músor megszerkesztése ebben az esetben nem vonzó alternatíva. A fogyasztók ilyen esetben szabadidejüket fogyasztásra (a professzionális músorszerkesztók által megszerkesztett tartalmak fogyasztására), nem pedig músorkészítésre (személyre szabott músor elóállítására) fordítják (Urbán 2003).

Más médiakutatók, így például a futurisztikus jövóképéról is ismert Negroponte (1995) szerint az új technológia egyben új típusú médiafogyasztást, az interaktív használatot is kialakítja. A szakirodalom a felhasználók új, interaktív típusára gyakran a desk potato elnevezést használja. Ez a kategória lényegében az internetjellegú, aktív használatot fedi le, beleértve az önálló músorszerkesztést is, de még nem tudjuk biztosan, hogy a fogyasztók döntố többsége valóban hajlandó lenne-e ilyen drasztikusan változtatni televíziónézési szokásain. Megjegyzendő, hogy ez a fogalom nem kizárólag a televíziózás esetében értelmezhetô, hiszen az online újságok szintén lehetôvé teszik a szelektív fogyasztást, a különböző szerkesztốségek tartalmainak egyéni összeválogatását. A szakirodalom az ilyen fajta, teljesen személyre szabott médiafogyasztást röviden a Daily Me kifejezéssel jelöli (Gálik 2002; Sparks 2002).

A couch potato és a desk potato jellegú médiahasználat közötti ellentétet a korlátozott interaktivitást megtestesító lazy interactivity, a „lusta interaktivitás” attitúdje oldhatja fel. A lazy interactivity arra utal, hogy a nézók hajlandók bizonyos erófeszítésekre a kívánatos tartalom elérése érdekében, de ezeknek az erófeszítéseknek a szintje erôsen 
korlátozott. Ehhez olyan felhasználóbarát alkalmazásokat kell kidolgozni, amelyeknek a használata egyszerú, és amelyek támogatják a gyors döntéshozatalt, folyamatosan kielégítve a fogyasztói igényeket.

Az interaktivitás terjedését nagymértékben meghatározza a különbözố technológiákhoz való hozzáférés és az azok által nyújtott médiatartalmak gazdagsága. Ettól függetlenül nem kétséges, hogy az eltérő használati attitűdök mögött más-más fogyasztói típusok állnak. Egy technológiai innováció esetében a terjedés korai szakaszában bekapcsolódó fogyasztóknak mások a jellemzóik, mint azoknak, akik késóbb válnak fogyasztóvá.

\section{Az innovációk diffúziójának általános elmélete}

Az új termékek és szolgáltatások terjedésének jól meghatározható trendje van, amit Rogers (2003) egy S-görbével írt le. A már a hatvanas években megszületett és azóta többször bizonyított elmélet szerint a legtöbb innováció esetében lassan alakul ki az a fogyasztói réteg, amely elkezdi használni az új szolgáltatást. Amikor a terjedés eléri a kritikus tömeget (matematikai értelemben ez a terjedési függvény inflexiós pontja), akkor a piac bôvülése felgyorsul, egyre többen és többen kapcsolódnak be a fogyasztásba. Az 1. ábra az innováció elfogadása szerint elkülöníthetố kategóriákat szemlélteti.

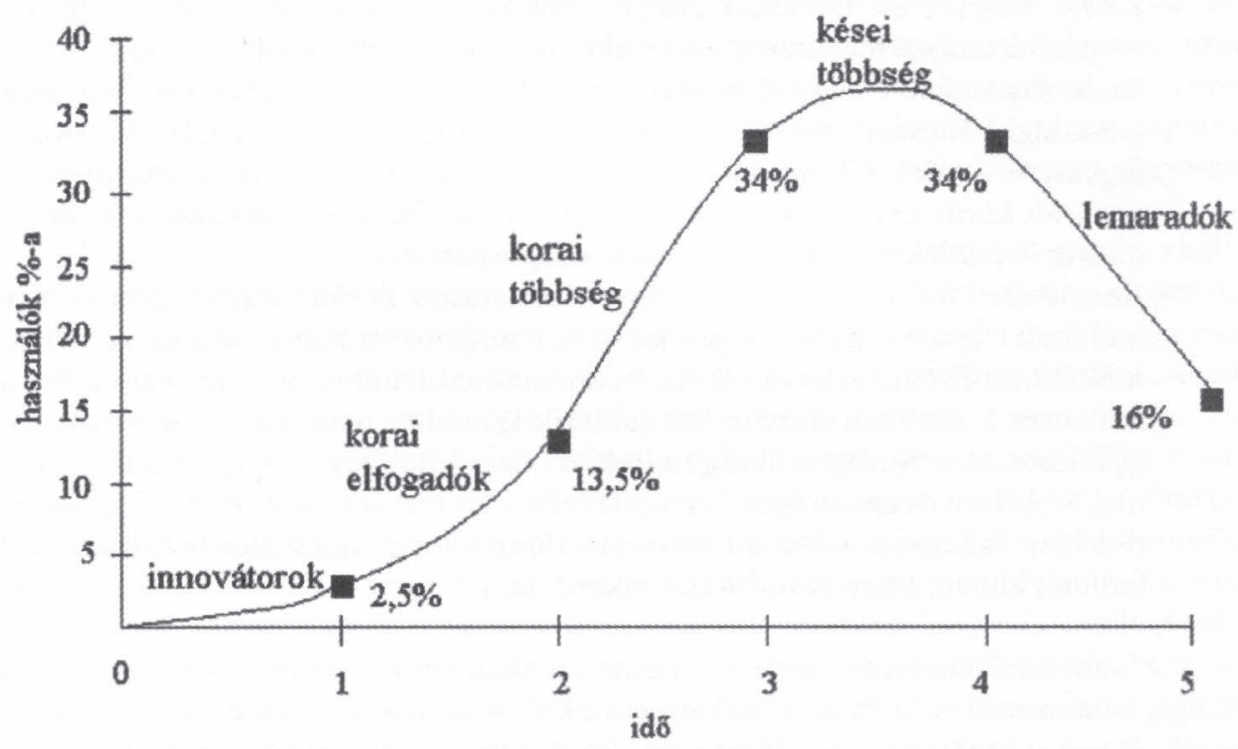

1. ábra. Az innovációk terjedése

Forrás: Rogers 2003, 281; és Weber-Evans 2002, 440.

Az innováció terjedése során az új termékek és szolgáltatások elfogadását vizsgálva egymástól többé-kevésbé jól elkülöníthetô öt fogyasztói csoportot írhatunk le. Az 
egyes kategóriák a szocioökonómiai státus, a személyiségjegyek és a kommunikációs viselkedés szerint egyaránt megkülönböztethetók egymástól (Rogers 2003):

$>$ Innovátorok (2,5\%): Az innovátorok az elsók között próbálnak ki minden újdonságot, ók elsốsorban nagyfokú vállalkozó kedvvel jellemezhetók. Rendszerint szükség van a technológia valamilyen szintú ismeretére, relatíve jó anyagi helyzetre és bizonyos kozmopolita gondolkodásmódra. Az is tipikus, hogy az innovátorcsoporton belül a nagy földrajzi távolságok ellenére is létezik az egyének között valamilyen kapcsolat.

$>$ Korai elfogadók (13,5\%): A korai elfogadók szorosabban integrálódtak a helyi társadalmi közösségbe, mint az inkább kozmopolita beállítottságú innovátorok. Ebben a csoportban különösen magas az ún. véleményvezérek aránya, a potenciális fogyasztók gyakran a korai elfogadók tapasztalataira támaszkodnak. Nincsenek elszigetelő́dve a környezetüktól, ezért az ô csatlakozásuk a fogyasztók táborához mérvadó a többség számára. Különösen fontos, hogy a korai elfogadók nagyban hozzájárulnak a kritikus tömeg eléréséhez.

$>$ Korai többség (34\%): A korai többség legjobban bizonyos megfontoltsággal jellemezhetô, ennek a csoportnak idő kell, amíg fogyasztóvá válik. Az innováció terjedése szempontjából már csak számossága miatt is fontos rétegról van szó, melynek tagjai nem tartoznak a véleményvezérek közé, de társadalmi kapcsolatrendszerük kiterjedt.

> Késối többség (34\%): Tömören szkeptikusoknak is nevezhetnénk óket, az ebbe a csoportba tartozó fogyasztók csak akkor hajlandók bekapcsolódni a fogyasztásba, ha a társadalom nagy része már kipróbálta az adott innovációt. Gyakran csak gazdasági kényszer vagy a személyes kapcsolatrendszer nyomására hajlandók fogyasztóvá válni. A késôi többség számára a biztonság különösen fontos: az innovációt körülvevố bizonytalanság teljes eloszlatása szükséges ahhoz, hogy ók maguk is csatlakozzanak a fogyasztók csoportjához.

$>$ Lemaradók (16\%): Itt a hagyományokhoz erôsen kötődő csoportról van szó, melynek tagjai a végsókig ragaszkodnak a megszokott fogyasztási és használati mintákhoz. Erôs gyanakvással viseltetnek minden innováció iránt, alapvetóen a múltat és a múltban történteket tekintik igazodási pontnak. A csoport tagjai gyakran társadalmilag is elszigeteltek, de hozzá kell tenni, hogy viselkedésük mögött bizonyos racionalitás is megfigyelhetoo: a lemaradók eróforrásai rendszerint igen szúkösek, tehát a fogyasztási döntés meghozatalakor biztosnak kell lenniük abban, hogy az innováció sikeres lesz.

Az innovációk sikere és a terjedés üteme azonban nemcsak a fogyasztók attitûdjétól függ, hanem attól is, hogy az adott terméknek vagy szolgáltatásnak milyen jellemzói vannak. Rogers (2003) az innovációk terjedésében a következő öt központi szerepet játszó tényezốt azonosítja: relativ elôny, összeegyeztethetốség, összetettség, kipróbálhatóság és megfigyelhetớség. Az innovációk adaptálásában ugyanakkor más tényezók is közrejátszanak, például a döntéshozatal módja, a kommunikációs csatorna jellemzói, a társadalmi közeg normái vagy a promóciós hatékonyság. 


\section{Az innovációk diffúziója az új médiaszolgáltatások piacán}

A hagyományos televíziónézéshez viszonyítva mind a digitális televíziózást, mind a hálózati platformon megvalósuló szolgáltatásokat a sokkal magasabb szintû́ interaktivitás relatív elốnye jellemzi. Az összeegyeztethetốség és az összetettség kérdése már problematikusabb: a fejlődés egyik akadálya éppen az lehet, hogy a fogyasztók egy része ezeknek az igénybevételét túlságosan bonyolultnak találja, és használatuk az ô számukra kevésbé vonzó, mint a televíziózás korábbi élménye. Ebból ered, hogy az interaktív szolgáltatások piacán alapvetố elvárásnak szokták tekinteni a felhasználóbarát megoldásokat és az egyszerúséget. A kipróbálhatóság nem jelent gondot, hiszen a fogyasztók minden különösebb következmény nélkül, fokozatosan ismerhetik meg az új szolgáltatásokat, és a terjedés egy adott szintje fölött a megfigyelhetőség sem jelenthet akadályt.

Ami a megfigyelhetốséget illeti, az interaktív szolgáltatások terjedése még nem tart ott, hogy a diffúziós elméletet egyértelmúen igazolni vagy cáfolni lehetne. A több platformon párhuzamosan végbemenő fejlődés, az üzleti modellek kialakulatlansága és az infokommunikációs szektorban az évtized elején tapasztalt pénzügyi instabilitás, valamint a fejlesztési programok visszafogása miatt az elméleti leírás még várat magára. Ráadásul úgy tû́nik, hogy az interaktív médiafogyasztást támogató technológiák - a korábbi várakozásokkal ellentétben - igen lassan fejlődnek: az Eurostat adatai szerint 2006-ban a háztartások internetpenetrációja az Európai Unió 25 országában átlagosan mindössze $32 \%$-ot ért el. A Dataxis (2006) felmérése alapján a digitális televízió penetrációs szintje a 2005. év harmadik negyedévében $24 \%$-os volt az EU-ban (27 országra számítva), és a kutatók számára ma már egyértelmúnek túnik, hogy a teljes vagy közel teljes ellátottság az interaktív szolgáltatások és technológiák piacán legfeljebb csak a nagyon távoli jövőben érhetô el. Mindezek ellenére az elmúlt évtizedekben különös figyelmet kapott az új kommunikációs technológiákhoz kapcsolódó innovációk terjedése és a fogyasztói szokások alakulásának vizsgálata.

Rogers (1986) szerint az új kommunikációs technológiák esetében mindenekelőtt három jellegzetességet kell figyelembe venni. Először is, a kritikus tömeg elérésének kérdését, hiszen a kommunikációs szolgáltatások értékét éppen az adja meg, hogy mások is használják óket. Gyakori példa erre a telefon: az elsố telefontulajdonos számára a készülék használati értéke nulla volt egészen addig, amíg mások elérhetôvé nem váltak a telefon segítségével. A megközelítés hátterében a mikroökonómiából ismert hálózati hatás törvénye áll, melynek értelmében az adott termék vagy szolgáltatás használati értéke a felhasználók számának növekedésével exponenciálisan nố. Az interaktív médiaszolgáltatásoknál ez az elmélet csak részben igaz, a felhasználók száma nem befolyásolja közvetlenül a mások számára érezhető hasznosságot. Itt afféle közvetett hatásról beszélhetünk, a használók számának növekedésével párhuzamosan ugyanis egyre többen fektetnek be a tartalom- és infrastruktúra-fejlesztésbe, s ezáltal bốvül az elérhetố szolgáltatások köre.

Másodszor, ki kell emelni, hogy az eddigi vizsgálatok elsősorban technológiák, vagyis olyan eszközök terjedésére irányultak, amelyeknek a legnépszerúbb alkalmazásait éppen a fogyasztói szokások alakítják, mintegy az eszközök „felfedezése” révén. Az internet használatát a kutatók sokáig csupán a televíziózás és az újságolvasás helyettesítốjeként vizsgálták, az e-mail, a chat és a különféle fórumok népszerúsége csak késóbb vált nyilvánvalóvá. A mobiltelefonok tekintetében is váratlannak nevezhető az SMS-ek 
népszerúsége, azzal pedig végképp nem számoltak a kutatók, hogy a mobiltechnológia elterjedése a közönségszavazásokon keresztül a televíziós iparágra is hatással lesz. Az infokommunikációs eszközök fejlesztése tehát egyfelól gondosan megtervezett mérnöki munka és üzleti tevékenység eredménye, másfelól azonban azt, hogy mely szolgáltatások válnak igazán népszerúvé, végsố soron a felhasználók döntik el.

Harmadszor, tekintetbe kell venni, hogy az infokommunikációs technológiák esetében nem is annyira az innováció elfogadása és a felhasználók köréhez való csatlakozás, hanem inkább a használat intenzitása a döntő. Rogers szerint az ilyen irányú kutatásokban a függố változónak nem a használatra vonatkozó döntést, hanem a használat mértékét kell tükröznie. Ezt a felfogást képviseli Livingstone (2002) is, amikor azt mondja, hogy a kormányzati stratégiák és fejlesztési programok középpontjába nem az elérés biztosítását, hanem a használat motiválását kellene helyezni, ami kétségkívül kissé problematikusabb.

Goldhammer (2006) az eszközök konvergenciáját a svájci bicskával állítja párhuzamba, és arra hívja fel a figyelmet, hogy mint ahogy a svájci bicskát is csak utazáskor használjuk, és otthon inkább a megszokott késeket és egyéb szerszámokat vesszük elő, ugyanígy az elektronikus eszközöknél sem akarunk minden funkciót egy készülékbe tömöríteni: éppen ellenkezóleg, minden eszköznek megvan a maga funkciója, és rendszerint ennek megfelelóen használjuk óket.

Az interaktív szolgáltatások terjedésének átfogó vizsgálata a Rogers-féle diffúziós modell alapján még nem történt meg, de egyes technológiákhoz kapcsolódóan már folytak kutatások. Kang (2002) az interaktív televíziózás egyik fó platformjának tartott digitális kábelszolgáltatások terjedését vizsgálta az innovációk terjedését leíró diffúziós modell felhasználásával. Megállapította, hogy az elmélet jól alkalmazható a digitális kábelszolgáltatás terjedésének leírására.

Lin (1998) a személyi számítógépek otthoni elterjedését vizsgálta. Eredményei alapján az elfogadók, a valószínú elfogadók és a nem elfogadók csoportja jól elkülöníthetố egymástól a demográfiai összetétel, a médiafogyasztás és a kommunikációs eszközök birtoklása szempontjából egyaránt. Más kutatásokkal összhangban ő is megállapította, hogy a televíziónézés és az otthoni PC-használat között van összefüggés, más médiumok esetében (lapolvasás, rádióhallgatás) azonban nem talált szignifikáns kapcsolatot.

Egy másik, a fax és az audioinformációs szolgáltatások terjedését vizsgáló tanulmány a személyes kommunikációval kapcsolatos változók fontosságát igazolta. Az életminôség mérsékelten magyarázta az elfogadást, a médiahasználati változók nem hoztak szignifikáns eredményt, a társadalmi indikátorok pedig csak a fax esetében voltak alkalmasak az elfogadás elốrejelzésére, az audio információs szolgáltatások esetében nem (Neuendorf et al. 1998),

Az internet terjedését vizsgálva Atkin és munkatársai (1998) igazolták, hogy az elfogadók és az elutasítók demográfiai szempontból különböznek egymástól, továbbá kimutatták, hogy az egyéneknek a technológiával kapcsolatos beállítódása döntô hatással van az elfogadásra. A médiahasználati szokásokat vizsgálva megállapították, hogy az internetkapcsolattal rendelkezố fogyasztók kevesebb idốt töltenek tévénézéssel, mint azok, akiknek otthonukban nincs internet-hozzáférésük.

A technikai innovációk terjedésének sebességét a fogyasztói attitûdök különbözôsége és az egymástól jól elválasztható fogyasztói csoportok létezése ellenére is fel lehet gyorsítani a megfelelő alkalmazások megtalálásával. A sikeres innovációk kifejlesz- 
tését segítheti az olyan alapvető tendenciák figyelembevétele, amelyek a fogyasztói igényeket az elmúlt években jellemezték. Az új média esetében azonban nehezíti a helyzetet, hogy a technológia túlságosan gyorsan fejlődik, a fogyasztói szokások csak lassan követik a változásokat. Az internet, különösen a széles sávú internet esetében ki kell emelni a multitasking megjelenését (Carey 2004; Wolf 1999). A felhasználók - jellemzően a fiatalok - már több tevékenységet is képesek egyszerre végezni, így például az internet böngészése közben televíziót néznek, és emellett esetleg még valamilyen chat programot is futtatnak. A fogyasztói szokások ilyen összetett változása nehézzé teszi egy-egy szolgáltatás terjedésének elórejelzését - erre mi sem vállalkozunk.

\section{A kutatás célja és módszerei}

A kutatás célja az új médiaszolgáltatások piacának vizsgálata volt, különös tekintettel az „innovátorok” és a „korai elfogadók” csoportjára. A kutatás során abból az alapfeltevésból indultam ki, hogy fejlett infokommunikációs környezetben elérhetốk különbözố platformokon nyújtott interaktív alkalmazások. A szolgáltatások elfogadását, használatát és a terjedés ütemét tehát elsôsorban nem a hálózat jellege határozza meg. A széles sávú internetkapcsolattal rendelkezô előfizetók jellemzóinek megragadása így információt adhat az interaktív szolgáltatások szélesebb értelemben vett piacáról és a diffúzió lehetốségeiról is, függetlenül az alkalmazott technológiától és platformtól.

A kutatás hipotézisei (H1-H5) a következók voltak:

H1: A széles sávú (broadband) szolgáltatások megjelenése és terjedése szerves fejlődés eredménye, s nem választható el az internethasználatnak a kilencvenes években megkezdődött terjedésétól. Az internethasználat ún. korai belépoóinek jellemzối a széles sávú szolgáltatások esetében is azonosíthatók.

Ez a hipotézis feltételezi, hogy a korai széles sávú előfizetóknek is ugyanazok a fóbb demográfiai jellemzốik, mint néhány évvel ezelótt a korai (telefonmodemes) internetfelhasználóknak. Ez a réteg jellemzóen fiatal, magas iskolai végzettségú és vezető beosztásban dolgozó felhasználókból tevốdik össze: ugyanez volt megfigyelhetô az internet terjedésének korai szakaszában a „korai belépók” körében.

H2: A széles sávú elófizetốk intenzív és extenzív módon, vagyis sok idôt rászánva és sokrétûen használják a világhálót.

E hipotézis a széles sávú elófizetók internethasználati szokásaira vonatkozik mind a szórakoztató, mind pedig az információs tartalmak tekintetében, valamint egyéb felhasználási módok (például a távmunka) területén.

H3: A széles sávú előfizetốk egy jól meghatározható csoportjában van hajlandóság a tartalomszolgáltatói szerepre is (a csoport tagjai saját honlapot készítenek, és azon rendszeresen elhelyeznek saját maguk által létrehozott tartalmakat).

E hipotézis alapján az interaktív médiahasználat során jellemzően előforduló ún. prosumer jelenséget, a fogyasztás mellett produktív tevékenységre való hajlandóságot vizsgáltam.

H4: A széles sávú háztartásokban a felhasználók köznapi információs szükségleteinek kielégítésében a világháló fontosabb szerepet játszik, mint a hagyományos médiumok (az újságok, a rádió és a televízió). 
H5: A széles sávú háztartásokban a tévéhasználat szignifikánsan eltér az átlagtól mind a televíziónézésre fordított idő, mind a nézett csatornák tekintetében.

Az utóbbi két hipotézis alapján a széles sávú háztartások médiahasználati jellemzôit vizsgáltam, az átlagostól eltérő fogyasztási jellemzók megragadására törekedve.

A hipotézisek ellenôrzésével megpróbáltam bizonyítani, hogy a széles sávú internethasználat egyéni szinten egy bizonyos folyamat eredménye. A korábban említett couch potato-desk potato átmenet nem valósulhat meg egyik napról a másikra, mintegy függetlenül a külsố tényezóktól, hanem olyan kísérôjelenségei vannak, mint az infokommunikációs eszközökkel való jó ellátottság, a hagyományos médiatermékek fogyasztásának az átlagostól eltéró jellege, az internetes tartalomszerkesztésben való részvétel. $\mathrm{E}$ folyamat vizsgálata nem ad pontos választ bizonyos tyúk-tojás problémákra (például azért fizetett-e elő valaki széles sávú internetre, mert eleve az átlagtól eltérően fogyasztotta a hagyományos médiatermékeket, vagy pedig azért alakított ki sajátos fogyasztási szerkezetet, mert idejét az internethasználat köti le), de a kutatásnak nem is ez volt az elsódleges célja. Ehelyett az „innovátorok” és a „korai belépók” jellemzóit igyekeztem megragadni.

A kutatás révén megválaszolandó fó kérdésnek (research question, $R Q$ ) azt tekintettem, hogy a széles sávú internet-elófizetốk használati szokásai és demográfiai, valamint médiafogyasztási jellemzói homogének-e, vagy éppen ellenkezóleg, nagyon is különböznek egymástól.

RQ: A széles sávú szolgáltatások elófizetôinek körében azonosíthatók-e az internethasználat alapján különbözó felhasználói csoportok, vagy a terjedés korai szakaszában a széles sávú előfizetók többé-kevésbé homogén csoportot alkotnak?

Különbözó kutatások kimutatták, hogy Magyarországon - csakúgy, mint máshol az internethasználat először a fiatal, magasabb státusú és magas iskolai végzettségú személyek körében terjedt el (Angelusz-Tardos 2004; Desewffy et al. 2003; Hargittai 2004; ITHAKA-ITTK-Tárki 2004). A kutatás során arra próbáltam választ kapni, hogy ez a szegmens a használati jellemzókból kiindulva tovább bontható-e.

Az empirikus kutatást a UPC Magyarország Kft. széles sávú internetszolgáltatásaira (chello) elófizetố személyek körében végeztem elektronikus úton terjesztett kérdôíves lekérdezéssel. A felhasználók a nekik küldött e-mail üzenettól egyetlen kattintással jutottak el a kérdőívhez, ennek kitöltése szintén egyszerú és gyors volt. A kérdőív 37 kérdést tartalmazott, ezek közül két kérdés esetében azonban - technikai okokból - nem történt adatrögzítés. Összesen tehát 35 kérdésre adott válaszokat dolgoztam fel.

Az e-mail üzenetek elküldésének idôpontja 2004. április 22. volt, az adatbázis lezárása 2004. június 28-án történt. Az adatfelvétel így több mint két hónapig tartott.

A kiküldött kérdőívek száma 48 011, a visszaküldött kérdő́ivek száma pedig 9849 volt, ez 20,5\%-os válaszadási hajlandóságot jelent. A ténylegesen elemzett mintába végül valamivel kevesebb, összesen 9771 válasz került be: a csökkenés a válaszok egy részének kiszúréséból adódott, amire például egymással megegyezóen kitöltött kérdőívek többszörös visszaküldése esetében került sor.

A kapott adatok feldolgozása SPSS-programmal történt.

Fel kell hívni a figyelmet arra, hogy a minta nem reprezentatív a magyar lakosság vagy akár csak a magyar internetezô lakosság egészére nézve. A vizsgált szolgáltatás ugyanis csak bizonyos földrajzi területeken érhetố el, és az ára a lakosság egy igen szé- 
les rétegét kizárja a fogyasztásból. Az internetes kutatásoknak egyébként általános jellemzố vonása, hogy a reprezentativitás - mivel nem tömegtermékról van szó - nem érhetố el, mert a társadalom igen jelentốs csoportjai nem tartoznak a fogyasztók körébe, és így a kutatásokban sem jelennek meg. A kábeles internetelérés földrajzi determináltsága miatt ez a minta még a széles sávú internetes közösséget sem feltétlenül reprezentálja.

\section{A minta jellemzői}

\section{Demográfiai összetétel}

A minta demográfiai összetétele nagyban különbözik a magyar lakosságétól. A fent említett okokból a reprezentativitás nem is lett volna elvárható, mégis érdemes megvizsgálni, hogy a széles sávú internetfelhasználók közössége milyen jellemzókkel írható le. Különösen feltûnô, hogy a vizsgált változók eloszlása eltér más, nem ennyire technológia-specifikus internetes kutatások (lásd például Angelusz-Tardos 2004) eredményeitól is.

A válaszadók 72,7\%-a férfi, 27,3\%-a nố volt. Ez annyiban meglepó, hogy az általános internetkutatások a vizsgálat idôpontjában ennél már sokkal kiegyensúlyozottabb nemi összetételt mutatnak. Ez a differencia az internet korai időszakára jellemző állapotokat idézi vissza. A széles sávú infrastruktúra használata tehát ebból a szempontból eltér az internethasználat egészétól.

A korcsoportok szerinti megoszlás azt mutatja, hogy kiugróan erôs a 18-49 éves, azon belül is a 18-29 évesek dominanciája. Ez nem meglepô: közismert, hogy a különbözố korosztályok internethasználati jellemzối között jelentôs eltérések vannak (Angelusz-Tardos 2004; ITHAKA-ITTK-Tárki 2004).

Az iskolai végzettség és a foglalkozás szerinti megoszlás bizonyítja, hogy az internet és ezen belül is a széles sávú internet használata a digitális szakadék egyik megjelenési formája. A minta közel fele felsófokú végzettségú, holott 2003-ban Magyarországon a 25-64 éves korosztálynak csak 14\%-a rendelkezett diplomával (KSH 2004). Jól ismert tény, hogy a különböző státusváltozók (például iskolai végzettség, jövedelem, foglalkozás) nem önmagukban befolyásolják az internethasználatot, hanem szorosan összefüggnek egymással.

A minta összetétele önmagában nem mond túlságosan sokat, annyi azonban megállapítható belóle, hogy egészen speciális szegmensról van szó. A demográfiai változók arra utalnak, hogy a chello-szolgáltatások átlagos felhasználója fiatal, városi, magas státusú férfi.

\section{Internethasználat}

Az internethasználat tekintetében a kérdések elsôsorban a világháló tömegkommunikációs médiumként való felhasználására vonatkoztak, és csak másodsorban érintették a kommunikációs lehetôségek kihasználását. 
1. táblázat. Az internet tömegmédiumként való használata a vizsgált mintában

\begin{tabular}{|l|c|}
\hline & $\begin{array}{c}\text { A válaszok gyakorisága } \\
(\%)\end{array}$ \\
\hline HÍRPORTÁLOK LÁTOGATÁSA & 71,0 \\
gyakorlatilag mindennap & 11,9 \\
hetente egyszer-kétszer & 15,5 \\
alkalomszerúen & 1,6 \\
soha & \\
\hline TELEVíżós PORTÁLOK LÁTOGATÁSA & 15,7 \\
gyakorlatilag mindennap & 13,0 \\
hetente egyszer-kétszer & 51,2 \\
alkalomszerüen & 20,0 \\
soha & \\
\hline INTERNETES RÁDIÓHALLGATÁS & 8,7 \\
gyakorlatilag mindennap & 8,1 \\
hetente egyszer-kétszer & 39,3 \\
alkalomszerúen & 43,9 \\
soha & \\
\hline
\end{tabular}

A válaszolók körében kiemelkedő a hírportálok, azon belül is a magyar nyelvú oldalak látogatása. Ehhez képest a legnépszerúbb médium, a televízió portáljai sokkal kevésbé népszerúek, ezeket a többség csak alkalomszerúen látogatja. Ezt a kérdést azért is vizsgáltam, mert van bizonyos várakozás a kutatók körében arra vonatkozóan, hogy a televíziós portálok fontossága elóbb-utóbb vetekszik majd a csatornákéval, különösen a márkanév építése és a fogyasztói hưség kialakítása terén (Swann 2000).

$\mathrm{Az}$ internetes rádióhallgatás egyre népszerúbb, ma már több ezer program érhetô el a világhálón keresztül. A rendszeres rádióhallgatók száma nem túlságosan magas, de meglepô, hogy a válaszadóknak több mint a fele hallgat - legalább alkalomszerúen internetes rádióállomásokat.

Külön vizsgáltam, hogy a fogyasztók mennyire használják ki a világháló interaktív jellegét, vagyis azt, hogy lehetőség van a tartalom igény szerinti összeválogatására, megvásárlására. A felhasználók túlnyomó többsége töltött már le internetes tartalmat, sốt ezt kifejezetten gyakran megteszi. (A kérdés egyértelmúen a tartalomszolgáltatás igénybevételére, például video- vagy zenei fájlok, játékok letöltésére vonatkozott. Az egyéb célokra, például a vírusirtó frissítésére végrehajtott letöltések nem tartoztak ide.) A tartalomért való fizetés kevésbé népszerú, de ez természetes. A fizetési arány még így is meglepóen magas ahhoz képest, hogy ez a kérdés is csak a tartalomra vonatkozott, tehát például az internetes pizza- vagy könyvrendelésre nem.

A prosumer jelenséget, vagyis a fogyasztó produktivitását, tartalomelőállítási készségét a saját honlap készítése, illetve üzemeltetése jelzi. A válaszolók közel negyedének van saját honlapja, ami arra utal, hogy nagyon sokan mutatnak érdeklődést a tartalomközlés iránt is. Szintén a felhasználók aktivitását bizonyítja - bár ez már nem a médiatartalomra utal - a távmunka lehetôségének rendszeres kihasználása. 


\section{A hástartások IKT-ellátottsága}

Az eddigi kutatások szerint a háztartások IKT-ellátottsága és az internethasználat között van összefüggés. Az új technológiák iránti érdeklődés, az innovációk elfogadása általában nem korlátozódik egy-egy konkrét termékre vagy szolgáltatásra, hanem ezek széles körére kiterjed. Az internetfelhasználók rendszerint nagy arányban rendelkeznek különféle más infokommunikációs eszközökkel is.

A minta sajátos vonásairól sokat elmond, hogy magasabb a mobiltelefonnal, mint a televízióval rendelkezô háztartások száma. A televízióval rendelkezố háztartások 96,7\%-os aránya valamelyest elmarad a teljes lakosságban mért értéktól, de a különbség nem jelentôs. (Az AGB Hungary adatai szerint Magyarországon a televíziós háztartások aránya 2004-ben 98,2\% volt, a Nemzeti Médiaanalízis eredményei ugyanakkor a 2004. év első félévére nézve $99 \%$-os arányt mutatnak.)

A mobilpenetráció 98,8\%-os értéke azonban a mintában kiugróan magasnak számít, ez lényegesen meghaladja a magyarországi átlagot. A Nemzeti Médiaanalízis 2004. elsố félévi adatai szerint a háztartások 64\%-ában található mobiltelefon, míg a Tárki 2003 őszén 67\%-os szintet mért (Szívós-Tóth 2004).

A válaszolók tulajdonában szintén nagyon magas arányban vannak különféle szórakozási célú eszközök (VCR, DVD, CD, játékkonzol), továbbá meglepóen magas, mintegy 45 \% az egynél több számítógéppel rendelkezó háztartások aránya is. Önmagában nem meglepó eredmény, hogy a széles sávú elófizetéssel rendelkező háztartások körében az országos átlagnál jobb a szórakoztató eszközökkel való ellátottság, hiszen jobb anyagi helyzetú és a modern technikától nem idegenkedố emberekról van szó. Az eltérés mértéke azonban meglepóen nagy, a kutatási minta ebból a szempontból markánsan eltér az átlagostól.

\section{Médiahasználati jellemzók}

A széles sávú internet-hozzáféréssel rendelkezố előfizetók csoportjáról feltételezhetố, hogy más médiahasználati szokásaik vannak, mint az internettel nem rendelkezố nagyközönségnek. Ha abból indulunk ki, hogy a válaszolók bevallásuk szerint naponta átlagosan 3,6 órát töltenek az internetezéssel, akkor sejthetô, hogy körükben a szabadidő-felhasználás és így a médiafogyasztás struktúrája is eltér az átlagostól.

A mintában jóval magasabb a politikai-közéleti napilapot olvasók aránya, mint a bulvárlapokat olvasóké. Az üzleti napilapokra vonatkozóan mért közel 20\%-os olvasottság kiemelkedôen magas, ez újfent bizonyítja a minta speciális összetételét. A megyei napilapok és az ingyenes napilapok olvasottságából nem lehet messzemenô következtetéseket levonni, mert ezeknek a beszerezhetôsége földrajzilag is determinált. 
2. táblázat. Újságolvasási sæokások a válaszadók körében

\begin{tabular}{|l|c|}
\hline & $\begin{array}{c}\text { A válaszok gyakorisága } \\
(\%)\end{array}$ \\
\hline ÚJSÁGOLVASÁS & 44,0 \\
$\quad$ politikai-közéleti napilap & 30,4 \\
bulvárlap & 27,8 \\
megyei napilap & 19,7 \\
üzleti napilap & 35,8 \\
ingyenes napilap & \\
\hline ÚJSÁGOLVASÁSI SZOKÁSOK VÁLTOZÁSA & 2,2 \\
többet olvas, amióta van széles sáv & 34,2 \\
kevesebbet olvas, amióta van széles sáv & 8,9 \\
ugyanannyit olvas, de mást & 54,7 \\
nem változott az olvasási szokás & \\
\hline
\end{tabular}

A Nemzeti Médiaanalízis 2004. I. félévi adatai a lakosság egészére nézve ettól egészen eltéró képet mutatnak. A politikai-közéleti napilapok olvasottsága 0,9-6,0\% között mozog (Népszava: 0,9\%, Magyar Hílap: 1,0\%, Magyar Nemzet: 2,4\%, Népszabadság: 6,0\%). Ez egyszerú összegzéssel is alig haladja meg a 10\%-ot, és akkor még nem is számoltunk az úgynevezett keresztolvasottság hatásával, ami az általam vizsgált szegmensben 3-32\% között van. Országos átlagban tehát 10\% alatt marad azoknak az aránya, akik minőségi napilapot olvasnak.

A bulvárlapok közül ebben az idôszakban csak a Blikk szerepelt a Nemzeti Médiaanalízisben, ennek az olvasottsága $12,4 \%$-ot ért el. Az üzleti napilapok olvasottsága azonban $1 \%$ alatt van (Napi Gasdaság: 0,3\%, Világgazdaság: 0,4\%, a keresztolvasottság $23 \%$, illetve 26\%). A megyei napilapok olvasottsága 0,4-2,9\% között mozog, a Metro pedig 5,8\%-ot mondhat magáénak. A megyei napilapok és a Metro esetében azonban figyelembe kell venni, hogy a mintánk földrajzilag nem reprezentatív, és ez nyilvánvalóan befolyásolja a nem országosan elérhetố lapok olvasottságát.

Megállapítható tehát, hogy a lapolvasási szokások markánsan eltérnek az átlagostól. Nem lehet ugyan figyelmen kívül hagyni a vizsgálatok eltérố módszereiból következő eltéréseket, de a különbségek túlságosan nagyok ahhoz, hogy kizárólag metodológiai okokra vezessük vissza óket. Kiderült, hogy a széles sávú eléréssel rendelkezók rendkívül aktív lapolvasók és az általuk olvasott lapok összetétele is sajátos képet mutat.

Különös figyelmet érdemel a lapolvasási szokások változása: a válaszadók harmada kevesebbet olvas, amióta van széles sávú internetelérése, és csak elenyészó arányban állítják, hogy többet olvasnak, mint korábban. Ez azért is fontos, mert a lapolvasási szokások fiatal korban alakulnak ki, tehát nem alaptalan a szakértóknek az az elôrejelzése, hogy az internet terjedése hosszú távon alapjaiban változtathatja meg a lapolvasási szokásokat.

A televíziónézési szokások feltérképezéséhez a válaszolóknak a leggyakrabban, a második leggyakrabban és a harmadik leggyakrabban nézett csatornát kellett megnevezniük. A nagyközönség tévénézési szokásait vizsgáló más kutatásokhoz hasonlóan ebben a mintában is a kereskedelmi televíziók dominanciája tapasztalható, de feltúnó a tematikus csatornák népszerúsége is. Fontos megjegyezni, hogy a mintában döntô 
többségben sokcsatornás háztartásokról van szó, legalábbis a kábeles infrastruktúra mindenütt rendelkezésre áll (ettól függetlenül persze elófordulhat, hogy a háztartás a széles sávú internetre elófizet, a kábeltelevíziós szolgáltatásra azonban nem, vagy a csupán néhány csatornát kínáló alapcsomagot választja).

3. táblázat. Televíziónézési szokások a válaszadók körében

\begin{tabular}{|l|c|}
\hline & A válaszok gyakorisága (\%) \\
\hline TELEVízIÓNÉzÉS & 36,7 \\
említett közszolgálati csatornát & 79,7 \\
említett kereskedelmi csatornát & 27,5 \\
említett dokumentumcsatornát & 18,6 \\
említett filmcsatornát & 14,5 \\
említett sportcsatornát & 8,3 \\
említett hírcsatornát & 4,2 \\
említett zenei csatornát & \\
\hline TÉvÉNÉzÉsi SZOKÁSOK vÁLTOZÁSA & 1,0 \\
többet tévézik, amióta van széles sáv & 48,5 \\
kevesebbet tévézik, amióta van széles sáv & 7,4 \\
ugyanannyit tévézik, de mást néz & 43,1 \\
nem változott a nézési szokás & \\
\hline
\end{tabular}

Jól látható, hogy a széles sávú elófizetés a televíziónézési szokásokat még inkább átrajzolja, mint a lapolvasás gyakorlatát. A tévénézéssel töltött idő 2,3 óra naponta, vagyis jóval kevesebb az internetre fordított idônél. Az AGB Hungary által mért adatok szerint 2004 májusában az átlagos magyarországi fogyasztó hozzávetóleg 4 órát televíziózott. A mintánk négyötödét kitevô 18-49 éves korcsoportban azonban már csak 3,6 óra, a legnagyobb gyakorisággal szereplő 18-29 éves korosztályban pedig 3 óra volt a tévézésre fordított idő (AGB Hungary, 2004). Hozzá kell tenni, hogy a széles sávú internetezốk kérdôíves lekérdezéséból származó eredmény és az AGB Hungary által mért adatok közvetlen összehasonlítása a módszertani különbségek miatt nem állja meg a helyét, az eltérés legfeljebb illusztratív jellegú lehet.

A válaszadók mintegy fele saját bevallása szerint kevesebbet tévézik, mint korábban, ami különösen annak fényében elgondolkodtató, hogy a magyar nyelvú hálózati videoszolgáltatások terén a tartalomfejlesztés az elófizetốk alacsony száma miatt valójában még meg sem kezdődött. A penetráció növekedésével ez nyilvánvalóan változni fog - mint ahogy az Axelero által 2004 végén bevezetett video-on-demand szolgáltatás esetében ez már tapasztalható is -, tehát nem kétséges, hogy a magyarországi músorszolgáltatóknak számolniuk kell a széles sávú hálózatok által teremtett versennyel.

\section{Az internethasználat típusai}

A következớ lépésben arra szerettem volna választ kapni, hogy az internethasználati változók alapján kirajzolódnak-e egymástól jól megkülönböztethető felhasználói típusok. Ennek érdekében az internethasználatra vonatkozó kérdések segítségével meg- 
próbáltam olyan faktorokat kialakítani, amelyek bizonyos használati dimenziókat írnak le. ${ }^{1}$ Minden korábbi kutatási eredmény azt bizonyítja, hogy a különbözố internetes alkalmazások nem függetlenek egymástól, így először én is a felhasználási formák közötti kapcsolatot próbáltam megtalálni.

Különböző változókészletek és módszerek kipróbálása után 16 változót vizsgáltam fókomponens-elemzéssel és Varimax rotációval. A KMO- (Kaiser-Meyer-Olkin-) mérôszám megfelelóen magas (0,673), a Bartlett-féle szferikus próba pedig szignifikáns eredményt adott.

A kommunalitások meglehetôsen magasak voltak, ez alól egyedül a távmunka tekinthetố kivételnek 0,3 alatti értékkel. A faktoranalízis lefuttatása után öt faktor alakult ki, amelyek együttesen a teljes variancia $47,75 \%$-át magyarázzák, a következố bontásban: 1 . faktor $11,5 \%$, 2. faktor $10,2 \%$, 3. faktor $9,7 \%$, 4. faktor $8,4 \%$, 5. faktor $7,9 \%$.

\section{4. táblázat. Rotált faktormátrix}

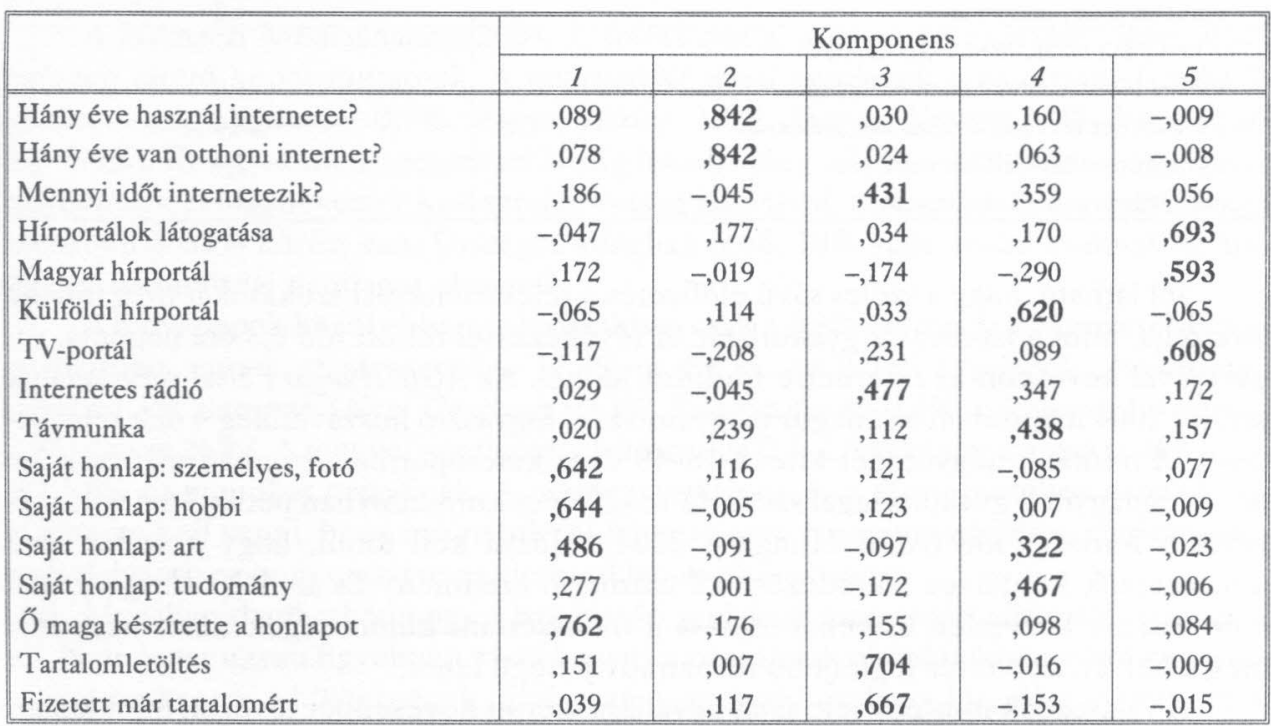

Az egyes faktorok aránylag karakteres felhasználási típusokat, illetve csoportokat ínak le:

1. faktor: prosumer jelenség

- honlapkészítés,

- a honlap rendszerint személyes információkat, fényképeket, múvészeti alkotásokat tartalmaz, illetve a hobbitevékenységre utal.

${ }^{1}$ A használatra vonatkozó kérdéseknél (például fizetett-e már tartalomért) a vizsgált használati forma gyakoriságára is rákérdeztem, például „nem, soha nem próbáltam”, „igen, de csak egyszer próbáltam”, „igen, többször is". 
A prosumer kifejezés az angol producer és consumer szavak összevonásából alakult ki, és arra a felhasználói attitúdre utal, amely a tartalom fogyasztása mellett a tartalom előállítását is magában foglalja. Látható, hogy a faktorban megjelenik más, fogyasztásra utaló változó is (például magyar hírportálok látogatása, tartalomletöltés), de igazán hangsúlyosan a tartalomszolgáltatói szerep olvasható ki. Az internetezéssel eltöltött idố nem túl sok, de pozitív értéket kapott.

\section{2. faktor: innovátor magatartás}

- régóta internetezik,

- régóta van otthoni internetelérése.

Ezt a faktort nem is annyira a használati szokások, mint inkább az internetezés korai kezdése jellemzi. Azok a válaszadók, akiknél ez a faktor magas faktorsúllyal szerepel - Rogers kifejezésével élve -, az internetezés magyarországi „innovátorai” voltak. Látható, hogy igénybe veszik a különbözó alkalmazásokat (hírportál-látogatás, távmunka, honlapkészítés), mégsem töltenek különösebben sok idốt a világhálón. Feltételezhetô, hogy ók már túl vannak a kezdeti lelkesedésen és a megismerés örömén, s ók már funkcionálisan, a napi életritmusukba illesztve használják az internetet.

3. faktor: a heavy user jelenség

- sok idốt töltenek internetezéssel,

- internetes rádióhallgatás,

- tartalomletöltések,

- fizetốs tartalmak vásárlása.

Az internetkutatásokból már többször is kiderült, hogy a felhasználók egy bizonyos csoportját teljesen leköti az internet. Szinte minden szabadidejüket a világhálón töltik, az alkalmazások széles skáláját kipróbálják, $s$ általában meg is vannak az ehhez szükséges technikai képességeik. A kapott eredmények azt mutatják, hogy ez a használati típus itt is azonosítható, az említett változók mellett jellemző még rá a televíziós portálok látogatása, a távmunka és a honlapkészítés is. Azok a válaszadók, akik erre a faktorra nézve magas faktorsúllyal szerepelnek, nem használják túlságosan régen a világhálót, tehát valószínúsíthetố, hogy egy részüket még a kezdeti lelkesedés is hajtja.

\section{4. faktor: sæakmai felhasænálás}

- sok idốt töltenek internetezéssel,

- külföldi hírportálok látogatása,

- internetes rádióhallgatás,

- távmunka,

- a saját honlap múvészeti, tudományos tartalmú.

A faktor az internethasználat széles skáláját tükrözi, de ez nagyon karakteresen eltér a heavy userek csoportjától. Kifejezetten igényes felhasználói viselkedésról van szó, feltételezhetô, hogy bizonyos kulturális elitet képez le ez a faktor. Jól érzékelteti ezt például a külföldi hírportálok nagyon magas pozitív és a magyarországi hírportálok viszonylag magas negatív értéke. A mintának azok a tagjai tehát, akiknél ez a faktor magas faktorsúllyal szerepel, kifejezetten preferálják a külföldi hírforrásokat a magyarokkal szemben. 


\section{5. faktor: tájékozódás}

- magyar hírportálok látogatása,

- televíziós hírportálok látogatása.

Ez a faktor meglehetôsen visszafogott, egysíkú használatot ír le. Itt a kiemelt hírkeresés mellett csak a távmunka és az internetes rádióhallgatás kapott pozitív eredményt, de ezek sem túlságosan magasak. Az „internetezés kezdete”, valamint az „otthoni internet-elófizetés kezdete" változók esetében valamennyi faktor közül ez kapta a legalacsonyabb értéket, tehát a mintát tekintve valószínúleg itt jelenik meg a legkésóbbi belépés a széles sávú internetezés piacára (a magyar társadalom egészét tekintve persze még itt is valamiféle innovátor-magatartásról beszélhetünk).

Összességében elmondható, hogy a viszonylag csekély számú internethasználati változóból is karakteres faktorok alakíthatók ki. A továbbiakban azt vizsgáltam, hogy ezeket a faktorokat milyen demográfiai, médiahasználati és IKT-ellátottsági mutatók jellemzik, illetve az egyes felhasználói csoportok között van-e különbség az internettel való megismerkedés és a korai tapasztalatszerzés tekintetében. Az eredmények túlnyomó része szignifikáns - ahol nem az, ott ezt külön jelzem a szöveges elemzésben.

\section{A felhasználói típusok jellemzése}

A faktorok felvázolják a fóbb felhasználói típusokat, és ezeken keresztül azokat a fogyasztói csoportokat, amelyekre az adott típusú használat jellemzô. Érdemes tehát megvizsgálni, hogy az így azonosított faktorok miként írhatók le a kutatásban szereplő demográfiai változókkal. Ugyanakkor azt is elemeztem, hogy az egyes faktorokban magas faktorsúllyal szereplő válaszadókat milyen médiahasználati szokások, illetve milyen számítógép-ellátottság jellemzi.

\section{Prosumer faktor}

Ebben a jellemzôen a férfiakhoz és a fiatal korosztályhoz tartozó válaszadók kaptak magas faktorátlagot. Valószínúleg az életkorból következik, hogy kiugró az általános iskolai végzettségúek aránya, ami azt sejteti, hogy a faktorban magas súlyt kapott személyek közül sokan középiskolába járnak. Az „érettségi” kategória szintén pozitív értéket kapott: ennek alapján talán megengedhetố az a feltételezés, hogy sokan éppen felsốfokú tanulmányaikat végzik. Ezt támasztja alá az is, hogy a „foglalkozás” változóban a „tanuló” kategória kapott kiugróan magas pozitív értéket. A „szellemi szabadfoglalkozást" leszámítva az összes többi foglalkozási kategóriánál negatív érték adódott, tehát ebben a csoportban nagyrészt tanulókról van szó.

A háztartásra vonatkozó változók esetében nem látható ilyen egyértelmú tendencia, a „háztartás létszáma” és a „fiatalok száma a háztartásban” nem adott szignifikáns eredményt. A fơváros dominanciájára utal azonban, hogy a „településtípus” változónál kizárólag Budapest szerepel pozitív értékkel. 
Ami a médiahasználati szokásokat illeti, a mintának azok a tagjai, akik ebben a csoportban magas faktorsúllyal szerepelnek, nem nevezhetók aktív újságolvasónak. Egyedül az ingyenes lapok esetében kapott az ,igen” válasz pozitív, a „nem” pedig negatív értéket, tehát a Metro címú lap a jelek szerint eléri a prosumer magatartással jellemezhetó fogyasztói csoportot. Az újságolvasási szokások változását kutató kérdésre a „többet olvas" kategória kapott pozitív eredményt, de ez nem bizonyult szignifikánsnak, mint ahogy a bulvárlapok olvasására utaló adat sem.

Szintén az életkorral magyarázható, hogy a televíziós csatornák között a zenei és némileg talán meglepő módon - a gyermekmúsorokat adó (elsôsorban rajzfilmeket közvetítố) csatornák kaptak magas pozitív értékeket. E csatornatípusok esetében az elemszám igen alacsony, ezért óvatosan kell bánni az eredménnyel. Észre kell venni, hogy a tévénézéssel töltött idő alacsony faktor: úgy látszik, hogy az aktivitást előtérbe helyezó prosumer felhasználók számára a passzív televíziónézés kevésbé vonzó alternatíva.

Összességében tehát elmondható, hogy az ebben a faktorban nagy súllyal szereplố válaszadók fóleg diákok, az ố internetes aktivitásukban, az ún. „prosumer jelenségben" minden bizonnyal komoly szerepet játszik a fiatal életkor. Ezek a mintatagok alacsony szintû napilap-olvasási hajlandósággal és visszafogott mértékú televíziónézéssel jellemezhetók, körükben leginkább a zenei és a rajzfilmcsatornák népszerúek.

\section{Innovátor faktor}

Ebben a faktorban - az elốzóhöz hasonlóan - szintén a férfiak részvétele túnik meghatározónak, ráadásul a prosumer faktorhoz nagyon hasonló faktorértékekkel. Jelentős különbség azonban, hogy itt a magasabb életkor kap pozitív, az alacsonyabb életkor pedig negatív értéket, tehát az idősebbek szerepelnek nagyobb súllyal ebben a faktorban. Az iskolai végzettséget tekintve látható a „felsőfokú” kategória kiugróan magas, valamint a „8 általános”, illetve a „szakmunkás” kategória alacsony értéke, ami a válaszadók magas kvalifikációjára utal. Ezt támasztja alá a „foglalkozás” változó is: a „tulajdonos/vállalkozó”, a „szellemi szabadfoglalkozású” és az „alkalmazásban álló értelmiségi” kategóriák kaptak pozitív értékeket.

A településtípust illetốen a fớvárosi lakosok dominanciája rajzolódik ki. A háztartás létszámát tekintve itt jelennek meg leggyakrabban az egyfős háztartások: ennek fényében nem meglepó, hogy 20 évesnél fiatalabb személyek kisebb számban vannak jelen ebben a faktorban.

Az eredmények azt mutatják, hogy a több számítógép megléte a háztartásban leginkább az innovátor faktorban jellemző. Miután itt már régi internet-elófizetókról van szó, valószínú, hogy az adatátviteli sebesség növekedésével egyre nagyobb teljesítményư számítógépre volt szükségük, tehát nem meglepố, hogy az ilyen háztartásokban több PC is található.

Az innovátorok újságolvasása jól láthatóan elsôsorban a politikai és közéleti napilapokra, illetve az üzleti napilapokra koncentrálódik, alátámasztva azt a korábbi megállapítást, hogy itt magas státusú csoportról van szó, amelyre - ezzel párhuzamosan - a bulvárlapok visszautasítása jellemzố. A faktorhoz tartozó válaszadók nem olvasnak megyei napilapokat: ez nyilvánvalóan visszavezethetố arra, hogy a demográfiai változók ta- 
núsága szerint jelentôs részben budapesti lakosok. Az újságolvasási szokásaik változását vizsgáló kérdés nem hozott szignifikáns eredményt.

Ami a tévénézési szokásaikat illeti, ebben a faktorban a legalacsonyabb a televíziózással töltött idő. Az eredmények alapján a nézés elsősorban a hírcsatornákat és kisebb részben a közszolgálati és a dokumentumcsatornákat részesítik előnyben.

\section{Heavy user faktor}

A heavy userek faktorán belül a legnyilvánvalóbb a „férfi” változó dominanciája. Életkor szerint is meglehetôsen homogén csoportról van szó, amely legnagyobbrészt fiatalokból tevődik össze. Ebból adódóan nem okoz meglepetést a „8 általános” iskolai végzettségű személyek magas faktorsúlya, annál érdekesebb viszont, hogy a „szakmunkás" végzettségú kategória is itt kapott kiugróan magas értéket. Ez azt jelenti, hogy ebben a faktorban nemcsak a tanuló fiatalok szerepelnek nagy súllyal, hanem azok is, akik az iskolarendszer alacsonyabb szintjén fejezték be tanulmányaikat. A „foglalkozás” változó tekintetében a tanulókon kívül a „gazda”, a „szakmunkás”, a „betanított munkás” és az „egyéb alkalmazott” kategóriákban is viszonylag magas volt az ide sorolható személyek aránya.

Tovább pontosítják a képet a háztartások településtípusok szerinti megoszlását tükröző változók. Kiderül, hogy ebben a csoportban a „város” kapja a legmagasabb eredményt (a „megyeszékhely” és a „község” is pozitív, de alacsonyabb értékkel szerepel). Talán nem alaptalan azt feltételezni, hogy az internethasználati szokások kialakulásában a lakóhely is nagy szerepet játszik, és sok helyen éppen az alternatív szórakozási lehetôségek hiánya tereli a fiatalokat az internet felé. A fơvárosi és a vidéki életmód közötti különbséget jelezheti, hogy ebben a faktorban egyáltalán nem jellemzóek a kis háztartások, sốt, a magas háztartáslétszám és a 20 évesnél fiatalabbak nagy száma éppen itt jelenik meg a legmarkánsabban.

Összességében azt láthatjuk, hogy a heavy user faktorhoz döntốen vidéki, még tanuló vagy tanulmányaikat már befejezett fiatal férfiak tartoznak. Azokra a válaszadókra, akik itt magas faktorsúllyal szerepelnek, nem jellemzô sem a felsôfokú végzettség, sem a magas társadalmi státus (ez a megállapítás természetesen a minta egészéhez viszonyítva értendő: ezek a felhasználók a saját mikroközösségükben ettól függetlenül lehetnek megbecsült, magas státust élvezó és véleményvezérnek tartott személyek).

A heavy user faktorban nagy súllyal szereplố válaszadók újságolvasási szokásai hasonlók a prosumer faktornál tapasztaltakkal. Az egyetlen jelentôs különbség abban áll, hogy ebben a csoportban megjelenik a bulvárlapok olvasása, ami a prosumereknél nem jellemzô. Ez talán összefüggésben állhat azzal, hogy itt jelentôs a vidéki felhasználók aránya, és ốk kevésbé jutnak hozzá a csak Budapesten és a nagyvárosokban terjesztett ingyenes napilaphoz. A megyei lapokra vonatkozó kérdés nem hozott szignifikáns eredményt.

Ami a televíziózási szokásokat illeti, ebben a faktorban kifejezetten a gyakori nézés kapott magas pozitív értékeket. Ez némileg meglepó, mert egyben azt is jelenti, hogy a sok internetezés mellett még a televíziómúsorok figyelemmel követésére is jut idő, tehát a szabadidő-felhasználás elsôsorban e köré a két médium köré koncentráló- 
dik. Ez megerôsíti azt a korábbi feltételezést, hogy az erre a faktorra jellemzô vidéki lakóhely befolyásolja a szabadidő eltöltését, és az alternatív lehetôségek hiánya növeli az otthoni médiafogyasztásra szánt idót.

A zenei és a rajzfilmcsatornák ebben a faktorban is magas értékeket kaptak, különösen az elóbbi kategória eredményei kiugróak. Ez talán összefüggésben van a televíziózással töltött idővel, hiszen a zenei csatornák élvezetére - hasonlóan a rádiózáshoz gyakran az úgynevezett „háttérfogyasztás” jellemzó. Elképzelhetố tehát, hogy a tévénézés és az internetezés gyakran párhuzamosan történik, így lehetséges, hogy a faktorba tartozók mindkét médium fogyasztására sok idốt szánnak. Itt is meg kell azonban említeni, hogy a zenei és a rajzfilmcsatornákra vonatkozó eredményeket az alacsony esetszámuk miatt fenntartásokkal kell kezelni, még akkor is, ha szignifikánsak. Egyértelmúen látszódik ennél a faktornál, hogy a közszolgálati és a hírcsatornák nem örvendenek nagy népszerúségnek.

Az eredményekból az is jól látható, hogy a széles sávú előfizetés megjelenése a legnagyobb mértékben az ebben a faktorban magas faktorsúlyú válaszadók tévénézési szokásait alakította át. A „,nem változott” kategória negatív értéke és a „kevesebbet tévézek" kategória pozitív értéke azt jelzi, hogy a tévénézéssel jelenleg eltöltött idő - holott ez sem kevés - korábban még több volt.

\section{Szakmai felhasะnáló faktor}

Az adatokból jól látható, hogy ez a faktor kevésbé karakteres, mint az elốzốekben tárgyaltak. A nemek szerinti összetételére nézve kapott eredmények nem bizonyultak szignifikánsnak, az életkor és az iskolai végzettség tekintetében pedig egyik kategória sem kapott túlságosan magas vagy alacsony értékeket, bár az utóbbit illetően a felsőfokú végzettség túnik a leggyakoribbnak. A foglalkozást tekintve azonban szembetûnó a szellemi szabadfoglalkozásúak kiugró értéke, ami arra utal, hogy az itt nagy faktorsúllyal szerepló válaszadók otthoni munkavégzésre is használják a számítógépet és a világhálót. A tanulók is 0,1 fölötti értéket kaptak, tehát minden bizonnyal megjelennek itt azok a felhasználók is, akik az iskolai feladatokhoz szükséges információkat keresnek az interneten.

A háztartásra vonatkozó változókat tekintve itt is gyakoriak az egyszemélyes háztartások, de érdekes módon a legnagyobb (hat fós vagy annál nagyobb) kategória is pozitív értéket kapott.

Látható, hogy a demográfiai változókkal ez a faktor kevésbé jól leírható, mint az eddigiek. Az eredmények azt mutatják, hogy nagy súllyal tartoznak ide azok a szellemi szabadfoglalkozásúak, akiknek az internetezés minden bizonnyal munkavégzést is jelent. Megjelennek azonban azok a tanulók is, akikre a korábbi faktorok által leírt használati szokások nem jellemzók, ók valószínúleg meglehetôsen funkcionálisan, feltételezhetốen a tanulmányokhoz kötốdố információkeresésre használják a világhálót.

A „szakmai felhasználók” faktorra a minóségi és az üzleti napilapok olvasása jellemzô. A többi laptípus és az olvasási szokásokat kutató változó nem kapott olyan értékeket, amelyekból határozott következtetéseket lehetne levonni.

A televíziózással töltött idő tekintetében nem fogalmazható meg olyan egyértelmú állítás, mint a többi faktornál, mindenesetre a legmagasabb értéket a „kevesebb 
mint 1 óra" kategória kapta. A csatornapreferenciák kapcsán azonban érdekes következtetéseket vonhatunk le. Az „egyéb” csatornák kiugróan magas értéke elsó látásra meglepő: a faktoranalízis során kiderült, hogy ebben a faktorban gyakori a külföldi hírportálok látogatása. Nem elképzelhetetlen tehát, hogy a „szakmai felhasználókra” a külföldi televíziós csatornák nézése is jellemzó, bár itt is figyelembe kell venni az alacsony esetszámot. Egyértelmúen látszódik azonban a hírcsatornák és a dokumentumcsatornák népszerúsége, míg a sportprogramok a jelek szerint kevésbé vonzók a szakmai felhasználók számára.

\section{Tájékozódás faktor}

Ez az egyetlen olyan csoport, ahol a „férfi” változó negatív, a „nô” változó pedig pozitív értéket kapott. Még ha alacsonyak is ezek az értékek, az eredmény szignifikáns, a nói felhasználóknak magas a faktorsúlyuk. A korcsoportokat tekintve kirajzolódik, hogy alapvetően az idősebb felhasználók tartoznak ide, az ,iskolai végzettség” változó azonban nem alkalmas semmilyen következtetés levonására. Annál érdekesebb ugyanakkor, hogy a „foglalkozás” változó tekintetében két olyan kategória is megjelenik, nevezetesen a nyugdíjasoké és a háztartásbelieké, amelyek kizárólag itt kaptak pozitív faktorértékeket.

A településtípus esetében nem rajzolódik ki világos tendencia, a háztartás nagyságára és összetételére utaló eredmények pedig nem szignifikánsak. Ettól függetlenül elképzelhetố, hogy az ide tartozó felhasználók egy része a családtagoktól tanulta az internet használatát, de a felhasználás a legegyszerúbb tevékenységre, a hírek keresésére irányul.

A tájékozódó faktorban magas faktorátlagot kapott válaszadók különösen aktív újságolvasók, az ingyenes lapok kivételével mindegyik kategóriánál meggyôzóen magas értékek adódtak. Kiderült továbbá, hogy a széles sávú internet megjelenése ennél a faktornál okozta a legjelentősebb változást az újságolvasási szokásokban. Ez azért is elgondolkodtató, mert a faktorban elsősorban nem a fiatalok szerepelnek nagy súllyal, tehát itt elvileg már kialakult és stabil médiafogyasztási szokásokról van szó. Mindenesetre a „nem változott” kategória negatív eredménye és az összes többi kategória 0,2-nél magasabb értéke azt sugallja, hogy a faktorban a magas értéket elérő válaszadók olvasási szokásai valóban átrendeződtek.

A tévénézéssel eltöltött idô meglehetốsen magas ebben a faktorban. A választási preferenciákról azonban ezúttal nem sokat tudunk meg, a napi többórás tévézésbe valószínúleg különbözố típusú csatornák is beleférnek. A nézési szokások változására irányuló kérdés azt sugallja, hogy ebben a faktorban is történt valamiféle átrendeződés, még ha nem is olyan jelentós mértékben, mint a heavy userek esetében.

\section{Következtetések}

Az empirikus kutatás célja az volt, hogy árnyalja a széles sávú internet-hozzáféréssel rendelkezố személyek gyakran homogénnek tekintett csoportjáról kialakult képet. Tudjuk, hogy a kábeles internetcsatlakozás ma Magyarországon leginkább a magas jövedelmú rétegek számára érhetố el. Az „internetes társadalomról” általában is él afféle 
sztereotípia a közvéleményben, miszerint itt elsốsorban fiatal, felsófokú végzettségú, magas státusú városi emberekról van szó, és ez még inkább érvényes a széles sávú hozzáféréssel rendelkezố rétegre. Annak elfogadása mellett, hogy az így kialakult képnek minden bizonnyal van alapja, mindazonáltal fontosnak tartottam a fó használati típusok feltérképezését.Az adatfelvétel idején a technológia a terjedés korai szakaszában volt, így a korai felhasználók jellegzetességeit vizsgáltam. Kiderült, hogy a demográfiai, a médiafogyasztási és az IKT-ellátottsági változók tekintetében ez a szegmens markánsan eltér az átlagostól. A chello-szolgáltatás eloofizetối párhuzamba állíthatók a rogersi elmélet alapján innovátornak tekintett csoporttal, ám a felhasználási szokások alapján további információkat kaptunk ennek a rétegnek a „finomszerkezetéról” és egyes szegmenseiról.

A demográfiai változók megmutatják, hogy a mintában erôsen felülreprezentáltak a felsơfokú végzettségúek, a fiatalok, a férfiak, a fóvárosiak és a vezető beosztásban dolgozók. Ez önmagában nem meglepó, hiszen szinte minden internetkutatás kimutatja, hogy a fó felhasználók többnyire a magasabb státusúak és a fiatalok köréból kerülnek ki.

A médiafogyasztással kapcsolatos változók kevésbé evidens eredményeket hoztak. A napilapok olvasottsága kiemelkedóen magas, különösen ahhoz képest, hogy sokan az internetet tartják a napilapok egyik fó helyettesítójének. Nem szabad persze elfelejteni, hogy a mintát legnagyobbrészt magas társadalmi és gazdasági státusú személyek alkotják, s ez az internettól teljesen függetlenül meghatározza a lapolvasási szokásokat. Elgondolkodtató azonban, hogy a válaszadók egyharmad része saját bevallása szerint kevesebbet olvas, amióta van otthoni széles sávú internetelérése. A televíziózással kapcsolatos változók a tematikus csatornák népszerúségét mutatják. Itt is figyelembe kell venni potenciális magyarázó változóként a minta speciális összetételét és azt is, hogy a kutatás jellegénél fogva olyan háztartásokról van szó, amelyekben elérhetók a kábeltelevíziós szolgáltatások. A válaszadók fele számolt be arról, hogy a széles sávú elérés óta kevesebb idốt fordít tévénézésre: ez - annak fényében, hogy az adatfelvétel idején a magyar nyelvú videotartalom kínálata a világhálón meglehetôsen szúkös volt - meglehetősen magas arány.

A kutatás következố lépéseként az internethasználati változókkal végeztem faktoranalízist, melynek segítségével öt egymástól jól elkülöníthetố felhasználói típust kaptam. Faktorátlagok számításával megvizsgáltam ezeket, és kiderült, hogy (1) a prosumer, (2) az innovátor, (3) a heavy user, (4) a szakmai felhasználó és (5) a tájékozódó felhasználói típusok, illetve az ezeknek a reprezentáltsága alapján azonosított csoportok elkülöníthetốk egymástól a már említett demográfiai és médiahasználati változók szerint.

A kutatás továbbfejlesztésének egyik iránya a széles sávú internet, tágabb értelemben az interaktív médiaszolgáltatások további terjedésének vizsgálata lehet. A rogersi S-görbe elsôsorban olyan innovációk leírására alkalmas, amelyek a népesség egészét érintik, s amelyeknek az elterjedtsége csaknem teljesnek mondható (ilyen például a televízió vagy a mobiltelefon). Közel sem biztos azonban, hogy az internet ilyen lesz, lehetséges, hogy a penetráció az elóbbieknél jóval alacsonyabb szinten megáll, a piac telítődik (Magyarországon példa erre a személygépkocsi). Alapkérdés tehát, hogy az interaktív média terjedése melyik fejlődési mintát követi majd (Angelusz-Tardos 2005). Más szerzók (Dessewffy-Galácz 2003) arra hívják fel a figyelmet, hogy az S-görbe megvalósulásának nem feltétele a 100\%-os (vagy ahhoz közeli) telítettség, a görbe alacsonyabb terjedési szinten is felrajzolható. 
A kutatás folytatásának másik iránya a széles sávú hozzáférés terjedése és a digitális szakadék alakulása közötti kapcsolat elemzése lehet. Érdemes volna megvizsgálni, hogy egy kisebb közösségben a széles sávú szolgáltatások elérése egyéni szinten - ceteris paribus - megváltoztatja-e az egyén pozícióját a közösségen belül, illetve alkalmas-e egész közösségek szocioökonómiai státusának javítására. Érdemes vona vizsgálni, hogy a kormányzati stratégiákban és fejlesztési programokban felbukkanó elképzelések (például a nyilvános hozzáférési pontok kiépítése, illetve a nagyközönség igényeinek megfelelố tartalomfejlesztés) valóban hozzájárulnak-e a szolgáltatások terjedéséhez. A kutatás felveti azt a kérdést, hogy a széles sávú internet terjedése valóban alkalmas-e a sokat emlegetett digitális szakadék csökkentésére. A távmunka lehetốsége, a tartalmak és szolgáltatások széles skálájához való hozzáférés és a földrajzi távolságok áthidalása elvileg lehetôvé teszi a kedvezốtlen társadalmi helyzetben lévő személyek és csoportok felzárkózását. Rogers (2001) azonban felhívja a figyelmet arra, hogy az internet inkább növeli a társadalmi különbségeket, mintsem csökkenti azokat. Ezt elsôsorban a hozzáférés (a számítógép, illetve a vezetékes kapcsolat) hiánya, valamint a demográfiai jellemzók és az iskolázottság, illetve a tanulási lehetôségek tekintetében fennálló különbségek okozzák.

A kutatás harmadik továbbfejlesztési iránya a médiahasználati szokások longitudinális elemzése lehet. Az internetnek a hagyományos médiatermékek fogyasztására tett hatására vonatkozóan inkább elốrejelzéseket, mintsem empirikusan igazolt kutatási eredményeket ismerhetünk. Ez részben érthetô, hiszen az internet csak a kilencvenes évek második felében kezdett látványosan terjedni, és ekkor kezdődött meg a szórakoztató, illetve információs tartalmak expanziója. A hosszú távú trendek felrajzolására eddig tehát nemigen volt mód, de lassan lehetségessé válik ilyen kutatások folytatása is.

\section{Irodalom}

AGB Hungary (2004). 2004. május - A televíziózásra fordított idô napi átlaga http://www.agb.hu/magyar/statisztikak/archiv/0405havi_atv_prof1.pdf

Letöltés dátuma: 2004. december 1.

Angelusz, R. - Tardos, R. (2004). Túl az egyötödön - a tudás- vagy az élménytársadalom felé? Jel-Kép, 2. szám.

Angelusz, R. - Tardos, R. (2005). Internet és egyenlótlenség. Egy „digitális Máté-effektus” körvonalai? Jel-Kép, 2. szám.

Atkin, D. J. - Jeffres, L. W. - Neuendorf, K. A. (1998). Understanding Internet Adoption as a Telecommunications Behaviour. Journal of Broadcasting \& Electronic Media, 42 (4), 475-490.

Carey, J. (2004). Audience Demand for TV over Internet. In Noam, E. - Groebel, J. - Gerbarg, D. (ed.): Internet Television. Lawrence Erlbaum.

Dataxis (2006). Digital Television Data. EU Market for Digital Television. Report Prepared for the European Commission. http://ec.europa.eu/information_society/policy/ecomm/doc/info_centre/studies_ext_ consult/digital_tv_final_report_cec.pdf

Letöltés dátuma: 2007. február 25.

Dessewffy, T. - Galácz, A. (2003). „A dolgok új rendje”: Technológiai diffúzió és társadalmi változás. In Dessewffy, T. - Z. Karvalics, L. (szerk.): Internet.hu - A magyar társadalom digitális gyorsfényképe. Budapest, Aula Kiadó, 31-60. 
Gálik, M. (2002). Value Added Services on Digital Television Platforms. The Public, Vol. 9 (4), $67-74$.

GfK Hungária - Szonda Ipsos (2004). Nemzeti médiaanalízis. I. félév.

Goldhammer, K. (2006). On the Myth of Convergence. In Groebel, J. - Noam, E. M. - Feldmann, V. (ed.): Mobile Media. Content and Services for Wireless Communication. Lawrence Erlbaum.

Hargittai, E. (2004). Internet access and use in context. New Media \& Society, Vol. 6 (1), 137-143.

ITHAKA-ITTK-Tárki (2004). A digitális jövoó térképe. A magyar társadalom és az internet. Budapest, World Internet Project.

Kang, M. (2002). Digital Cable: Exploring Factors Associated With Early Adoption. Journal of Media Economics, 15 (3), 193-207.

KSH (2004), Központi Statisztikai Hivatal: Magyarország 2003. http://portal.ksh.hu/pls/ksh/docs/hun/xftp/idoszaki/pdf/mo2003.pdf Letöltés dátuma: 2004. december 17.

Lin, C. A. (1998). Exploring Personal Computer Adoption Dynamics. Journal of Broadcasting \& Electronic Media, 42, 95-112.

Livingstone, S. (2002). Young People and New Media. Childhood and the changing media environment. London, Sage.

Negroponte, N. (1995). Being Digital. London, Hodder\&Stoughton.

Neuendorf, K. A. - Atkin, D. - Jeffres, L. W. (1998). Understanding Adopters of Audio Information Innovators. Journal of Broadcasting \& Electronic Media, 42, 80-93.

Rogers, E. M. (1986). Communication Technology. The New Media in Society. New York, The Free Press.

Rogers, E. M. (2001). The Digital Divide. Convergence, Vol. 7 (4), 96-111.

Rogers, E. M. (2003). Diffusion of innovations. Fifth edition. New York, Free press.

Sparks, C. (2002). The Impact of Internet on the Existing Media. In Richards, M. (ed.): The Internet and modern communications. Proceedings of seminar held at Intercollege Nicosia, Cyprus.

Swann, P. (2000). TV dot COM. The Future of Interactive Television. New York, TV Books.

Szívós, P. - Tóth, I. Gy. (szerk.) (2004). Stabilizálódó társadalomszerkezet. Tárki Monitor Jelentések 2003. http://www.tarki.hu/adatbank-h/kutjel/pdf/a530.pdf

Letöltés dátuma: 2004. december 17.

Urbán, Á. (2003). A nézố természeete avagy az interaktív televíziózás piaci fogadtatása. Jel-Kép, 4. szám, 47-59.

Weber, I. - Evans, V. (2002). Constructing the meaning of digital television in Britain, the United States and Australia. New Media \& Society, Vol. 4 (4), 435-456.

Wolf, M. J. (1999). The Entertainment Economy. How Mega-Media Forces Are Transforming Our Lives. New York, Times Books. 